\title{
THE EFFECT OF CONTEXTUAL COMIC STRIP ON EIGHTH GRADE STUDENTS' READING COMPREHENSIONAT SMP NEGERI 6 SINGARAJA
}

\author{
Sosiawan, M.Y. \\ English Education Department, Ganesha University of Education \\ e-mail: yahyasosiawan@gmail.com \\ Marhaeni, A.A.I.N. \\ English Education Department, Ganesha University of Education \\ e-mail: ngr.marhaeni@undiksha.ac.id \\ Dewi, N.L.P.E.S.D. \\ English Education Department, Ganesha University of Education \\ e-mail: sulistia.dewi@undiksha.ac.id
}

\begin{abstract}
The main objective of this experimental study was to investigate whether there is a significant effect of contextual comic strips strategy on students reading comprehension. The study was conducted at the eighth-grade students of SMP Negeri 6 Singaraja. This Posttest-Only Control group design was applied. The population in this study was all of the students at SMP Negeri 6 Singaraja in the academic year 2018/2019. The sample in this study was 60 students consisting of 30 students from the VIII B1 class as the experimental group and 30 students from VIII B2 as the control group. The sample was selected by using cluster random sampling technique. The data were collected through a post-test in the form of multiple-choice test. The data were analyzed by using t-test in SPSS 16.0 program. The result of this study revealed that the mean score for the experimental group (73.17) is higher than the control group (69.00). The result of the ttest also showed that the value of Sig. (2-tailed) was 0.025. Since the value of Sig. (2tailed) was below 0.05, the null hypothesis was rejected and the alternative hypothesis was accepted. Based on the result, it can be concluded that there was a significant effect of Contextual Comic Strips on eighth-grade students' reading comprehension at SMP Negeri 6 Singaraja in the academic year 2018/2019.
\end{abstract}

Keyword: Comic Strips, Contextual Comic Strips, Reading Comprehension

\section{INTRODUCTION}

English is an international language that plays an important role in some aspect of life. English is one of the important languages to communicate with others around the world. It is better for people to master English well. In school, there are four skills that should be mastered by students in learning English. There are speaking, reading, listening, writing. From that skill, reading is one of the language skills that should be mastered by EFL students. Reading is an activity to reveal the meaning of the letters in the written texts (Smith.2001). Reading is important in the context of a foreign language learning because it is the main source for the student to obtain the input language. The main goal of reading is to gain the correct message from a text that the writer wants the reader to receive (Ahmadi, 2017). 
Reading is one of the important academic skills in the teaching and learning process. By reading, the students can improve their knowledge about the information in the world. This statement is also supported by Gallik (1999), he said that reading also can develop the creative side of people. When we are reading, we obtain the knowledge and experience of other people. We can learn something from the experience of other people and develop our mind and language skills by discovering a new thing from the texts. From reading, we can understand many topics such as how to make something, how to make a better plan, how to find a job, and more. In order to achieve the goal, reading and comprehension skills are needed.

Duke and Pearson (2008) states that comprehension is a process of how the readers make the meaning by communicating with the text, a combination of words and the information from the written text. This statement is supported by Westwood (2008) who states that reading comprehension is the level of the reader's understanding of the information presented in a passage of a text. It is a process of comprehending texts, understanding the meaning and getting the information from the texts.

Based on the curriculum of 2013, reading in the learning process is part of the English subject which aims to help students comprehend the reading materials in the classroom. However, this is the most challenging task for students. According to Rukmini (2004), the problem of reading that faced by students in Indonesia is the strategy and the reading material used by the teacher. The lack of interest to read the book due to the students' prior knowledge, unable to comprehend the reading text, and also the complex structure of the book. Reading in the class considered boring because of unfamiliar vocabulary and lack of pre-reading activities, and long reading text (Firmanto, 2005). Therefore, it is expected that the teacher in the reading class uses an interesting strategy to motivate students in reading. Other than an interesting strategy, appropriate reading material is also needed to make students easier to understand and comprehend the text.

According to Perfetti (2006), poor decoding skill is one of the factors that causes poor reading comprehension. When reading students tend to spend much time to read and translate the words because they are unfamiliar of the new vocabulary (Firmanto, 2005). They only focus on finding the meaning of difficult words in the reading text rather than trying to comprehend the text. This problem will make students have difficulty in answering the comprehension questions.

As the problem still happens, the students will have low interest and motivation toward reading in learning English. According to Kweldju (1996), the model of teaching considered boring because of some factors such as unsuitable reading material due to the length of the text and also the strategy used by the teacher in the class. The strategy that is used by the teacher only answering questions based on the text, and retelling the context of the text (Firmanto, 2005).

Majidi \& Aydinlu (2016), mention that visualization can be used as an efficient strategy for meaningful learning. Through visualization can encourage students to make a personal connection to the text. Therefore, it is better for the teacher to use some pictures and less difficult words in reading materials. It will make the reading class become more interesting. There are many strategies can be used for helping and improving students' reading comprehension. One of them is a comic strips strategy.

In this research, the contextual comic strips strategy is applied in order to help students to comprehend the text better. According to Cheesman (2000), comic strips can be used to get students' attention, stimulate critical thinking of the students. Comic strips 
are a book that contains text with interesting pictures. The picture in comic strips expresses the information in the text (Cho, 2012). The pictures in the comic strip give students more detail information about the description, setting, and expression of the characters. Those will give students a good comprehension of the story rather than reading the conventional reading texts given by the teacher. Visuals help the reader to memorize the information. Decoding, visuals spark the readers' interest in the text. Liu (2004) explains that in accordance with Dual Coding Theory (DCT), the combination between the text and illustration produced better result rather than the text alone.

Based on previous research that was conducted by Dewi (2012), comic strip was implemented to improve students' reading comprehension in narrative text. She discovered that comic could build the creative side of students and increase students' reading comprehension. The picture gave students more detail information and helped the student to understand the language. Gorjian (2016) implemented downloaded comic strips stories on vocabulary learning-intensive reading courses among intermediate English learners. in this research, he used comic pictures to make students easily to understand the meaning of the words. The result showed that the experimental group in this research had a significant improvement after treatment on vocabulary learning. Furthermore, Seventilofa (2013) implemented comic strategy and learning style upon students' narrative reading competencies an experimental. He asked his students to read the narrative text by using comic strip strategy. He used manga (comic book) that was taken from the internet to teach reading comprehension. It was easier for his students to understand the content of the story. the result of the study showed that this strategy was effective for the students to improve their reading comprehension.

So, the use of pictures in the comic strip can make students have better reading comprehension. Other than that, comic strip is also more communicative and popular. The use of comic strips in the learning process will be more effective. Csabay (2006) also states that there are some advantages of using the comic strip as a media of learning such as comic strip because is does not only contain words alone but also picture. The comic strip also can improve the grammatical competence of students. The picture of comic strip helps students comprehend the text better and make the students understand the text easily.

According to Fukuyama (2006), In teaching using the picture, the use of picture contextually in reading does not only provide the reader with the background information but also make them more familiar with the context in the text. The used of contextual comic strips where the students can understand and are familiar with the situation will make them easier to understand the text. Majidi and Aydinlu (2016) state that when people know the context in the picture, they will use this knowledge to identify the object they see. Therefore, teaching using contextual comic strips can provide the situation and illustration that students familiar with the characteristic, culture, and situation that happen in the story. When we understand the scene in the picture, it would be easier to understand the content of the story.

Based on the preliminary observation that was conducted at SMP Negeri 6 Singaraja, it was found out that the students showed low comprehension of reading and the teacher used conventional reading strategies. In this case, most students had difficulty in comprehending text. Considering the aforementioned issue, the use of contextual comic strips in learning can offer greater benefits to the students' reading comprehension. Thus, the current study was conducted in order to investigate the effect of contextual comic strips showed on the students' reading comprehension. Specifically, 
it reseached the eighth-grade students at SMP Negeri 6 Singaraja in the academic year $2018 / 2019$.

\section{METHOD}

This experimental research used the Posttest-Only Control group design. This research used a quantitative approach in order to test a theory. This design involves two groups of samples called the experimental group and control group that were selected randomly by using a lottery. The experimental group was taught by using a contextual comic strip, and the control group was taught in a conventional strategy. It is used to investigate the difference score between the two groups. The score of the two groups analyzed by using statistical significance ( $t$-test) in order to know whether there is a significant effect of using contextual comics on students reading comprehension.

The population in this study was all of the students at SMP Negeri 6 Singaraja in the academic year 2018/2019. The sample in this study was 60 students consisting of 30 students from the VIII B1 class as the experimental group and 30 students from VIII B2 as the control group. The sample was selected by using cluster random sampling technique. The data were collected through a post-test in the form of multiple-choice test. The data were analyzed by using t-test in SPSS 16.0 program.

\section{FINDING AND DISCUSSION}

According to Wallen and Fraenkel (1997), the descriptive statistic is used to describe information from the sample of the group in many scores such as the mean, median, mod and more about these in a moment. Descriptive statistics in this study was done by analyzing the data from each sample of groups, experimental and control groups. In descriptive statistics, the data analyzed in the term of mean, standard deviation, variance, range, maximum score, and minimum score. The result of descriptive statistic analysis in this study can be seen in the table 4.1.

Table 4.1 The Distribution of Data

\begin{tabular}{|c|c|c|c|}
\hline \multirow{2}{*}{$\begin{array}{c}\mathrm{N} \\
\mathrm{o}\end{array}$} & \multirow{2}{*}{ Statistic } & \multicolumn{2}{|c|}{ Group } \\
\cline { 2 - 4 } & & Experimental $(\mathrm{N}=30)$ & Control $(\mathrm{N}=30)$ \\
\hline 1 & Mean & 73.17 & 69.00 \\
\hline 4 & Standard of Deviation & 7.008 & 6.998 \\
\hline 5 & Variance & 49.109 & 48.996 \\
\hline 6 & Range & 30 & 20 \\
\hline 7 & Maximum Score & 90 & 80 \\
\hline 8 & Minimum Score & 60 & 60 \\
\hline
\end{tabular}

The table on Table 4.1 showed that the mean score of the students who were taught using Contextual Comic Strips Strategy was 73,17. While the mean score of the students who were taught using conventional strategy was 69.00. It can be said that experimental group achieved higher score than control group $(73,17>69.00)$. Therefore, we can conclude that the achievement of experimental group was better than control group. Based on the result above about the descriptive statistic analysis, it can be said that the students who were taught using comic strips strategy had better reading comprehension rather than the students who were taught by using conventional strategy In this study, the use of comic strip in teaching students was able to make students better in reading and comprehend the words in the text. comic strips can facilitate 
students reading comprehension which helps students to comprehend reading text better.

The study was an experimental study that used Posttest-Only Control group design. This research was an experimental study that investigated the effect of the contextual comic strip in reading a teaching on eighth-grade students' reading comprehension at SMP Negeri 6 Singaraja. The population of the study was eighthgrade students of SMPN 6 Singaraja in the academic year 2018/2019. Two groups were taken from the population. The group was chosen by using cluster random sampling technique. The two groups were received 6 meetings treatment before the data were collected. The result of the students' reading comprehension post-test was descriptively and inferentially analyzed by using SPSS 16.0 to answer the research problems. In this study, the experimental group showed better reading comprehension. The most important thing was showed from the inferential statistical analysis, the score of Sig. (2tailed) was. 025 or $0.025(n=30)$ which meant that the significance value of the data was lower than the alpha value was 0.05 or $.05(5 \%)$. It could be seen that the null hypothesis was rejected and the alternative hypothesis was accepted.

Thus, it could be said that the Contextual Comic Strips had a significant effect on eighth-grade students' reading comprehension at SMP Negeri 6 Singaraja in academic year 2018/2019.

\section{CONCLUSION}

Refering the result of descriptive statistic, and inferential statistic analysis that had been presented on the previous chapter, it could be concluded that the use of Contextual Comic Strips for teaching reading comprehension of eighth grade students gave a significant difference on students' reading comprehension. It could be stated that the implementing of Contextual Comic Strips strategy for teaching reading comprehension for the eighth-grade students brought a better achievement than the students who were taught using conventional strategy It could be seen from the statistical analysis was found that the mean score of students' reading comprehension in experimental groups was higher than the mean score of the students in control groups.

\section{REFERENCES}

Abanomey, A. (2013). Do EFL Saudi learners perform differently with online reading? An exploratory study. Journal Of King Saud University - Languages And Translation, 25(1), 1-11. http://dx.doi.org/10.1016/j.jksult.2012.12.001

Ahmadi, M. (2017). The Impact of Motivation on Reading Comprehension. International Journal Of Research In English Education, 2(1), 1-7. http://dx.doi.org/10.18869/acadpub.ijree.2.1.1

Brown, H. D. (2007). Principles of language learning and teaching. New York: Pearson Bulgren, J. A.,

Cain, K. J., Oakhill, J., \& Bryant, P. (2004). Children's Reading Comprehension Ability: Concurrent Prediction by Working Memory, Verbal Ability, and Component Skills. Journal of Educational Psychology, 96(1), 31-42

Cheestman, K. (2006). Using Comics in the Science Classroom. Journal Of College Science Teaching. , 35(4), 48-51

Cho, H. (2012). The use of cartoon as ateaching tool in midle school mathematics.Unpublished doctoral dissertation, Teachers Collage, Columbia University, New York 
Cohen, L., Manion, L., \& Morrison, K. (2007). Research method in education (6thed.). London and New York: Routledge.

Csabay, N. (2006). Using comic strips in language classes. English Teaching Forum, $44(1), 24-26$

Csabay, N. (2006). "Using Comic Strips in Language Classes". English Teaching Forum OnLine, 44 (1), 24-26. Retrieved on February 22, 2017 from, http://www.exchanges.state.gov/forum/vols/vol44/no1/p24.htm

Dewi, h. (2012). The use of comic strip as Media to improve the reading comprehension of narrative text of the tenth Grade students of SMAN 1 Karangayung Purwadadi in the academic year 2011/2012. Retrieved from : http://eprints.umk.ac.id/1201/1/Cover and abstrak.pdf

Duke, N. K., \& Pearson, P. D. (2008). Effective practices for developing reading comprehension. Journal of Education, 189,1/2.

Firmanto, S. O. 2005, March. Students behavior of reading comprehension: Expectations and follow up. Paper presented at LIA International conference, Jakarta. Goodman

Fraenkel, J., \& Wallen, N. (2008). Student mastery activities to accompany How to design and evaluate research in education, seventh edition. New York, NY [etc.]: McGraw-Hill.

Fukuyama, Y. (2006). Effects of contextual visuals as advance organizers on L2 reading comprehension. ことばの科学， 19，185-202. https://mail.lang.nagoyau.ac.jp/bugai/kokugen/nichigen/0kyouiku/research/kotoba/19/13FUKUYAMA1 9.pdf

Gallik, J.D. (1999). Do they read for pleasure? Recreational reading habits of students. Journal of Adolescent and Adult Literacy, 42 (6): 480-488

Gorjian, B. (2016). Using Comic Strip Stories to Teach Vocabulary in Intensive Reading Comprehension Courses. The International Academic Forum.

Grabe, W. And Stoller, F. L. (2011). Teaching and Researching reading. great Britain: Pearson Educationa Limited

Harmer, J. (2001). The Practice of English language Teaching. Harlow: Longman

Kweldju, S. 1996. English department students interest and strategies in reading their content area textbooks. TEFLIN Journal, 8(1): 104-117

Liu, J. (2004). Effects of Comic Strips on L2 Learners' Reading Comprehension. TESOLQuarterly, 38(2), 225. http://dx.doi.org/10.2307/3588379

Majidi, N. and Aydinlu, N. (2016). The Effect of Contextual Visual Aids on High School Students' Reading Comprehension. Theory and Practice in Language Studies, 6(9), p.1827.

Marianthi, V., Boloudakis, M. and Retalis, R. (n.d.). From Digitised Comic Books To Digital Hypermedia Comic Books: Their Use In Education. University of Piraeus Department of Technology Education and Digital Systems.

Marleni, D. (2013). The effect of Comic Strips and Learning Motivation toward the Students' Achievement in English Writing in Eighth Grade of SMPN 2 Sawan. E-Journal Program Pascasarjana Universitas Pendidikan Ganesha Program Studi Pendidikan Bahasa Inggris.

Masduqi, H. (2014). Efl Reading In Indonesian Universities: Perspectives And Challenges In Cultural Contexts. Journal Of Teaching And Education, 386-392

McCloud, S. (1994). Understanding comics: The invisible art. New York: HarperPerennial 
McVicker, C. (2007). Comic Strips as a Text Structure for Learning to Read. The Reading Teacher, 61(1), 85-88. doi: 10.1598/rt.61.1.9

Palmer, H.E. (1964). The Principles of Language Study. London.

Perfetti, C. A., Landi, N., \& Oakhill, J. (2005). The acquisition of reading comprehension skills. In M. Snowling, \& C. Hulme (Eds.), The Science of Reading: A Handbook (pp. 227-247). Oxford, England: Blackwell

Rukmini, D. 2004, October. Genre analysis of the reading texts in the English text book for for high school students published by Balai Pustaka. Paper presented at the 52nd TEFLIN Conference, Palembang.

Seventilofa, O. (2013). The Effect Of Using Downloaded Comic Strategy And Learning Style Upon Students' Narrative Reading Competencies. E-Journal Program Pascasarjana Universitas Pendidikan Ganesha Program Studi Pendidikan Bahasa Dan Sastra Indonesia, 2.

Smith, C. (2001). A quality evaluation of the Schoolwide Early Language and Literacy (SWELL) program in Maitland-Newcastle Diocesan Catholic schools. Retrieved from: http://mn.catholic.edu.au/projects/evaluation.pdf

Templer, B. (2009). "Graphic novels in the ESL classroom". Major Article, 11(3). Retrieved from. http://www.hltmag.co.uk/june09/mart03/htm

Westwood, P. (2008). What teachers need to know about reading and writing difficulties.Camberwell, Vic.: ACER Press 